\title{
Precious Metals And Retirement Portfolio Survival Rates
}

Carl M. Hubbard, Trinity University, USA

Daniel T. Walz, Trinity University, USA

\begin{abstract}
Recent gains in the value of gold bullion in the presence of declines in the stock and corporate bond markets suggest that retired investors may benefit from holdings of precious metals. Because of the comparative liquidity and economy of holding mutual fund shares, we examine the effect of an optimal allocation of precious metals funds shares on portfolio survival rates through payout periods of 15, 20, 25, 30, and 35 years using returns data from September 1988 through December 2008. Since most of the higher withdrawal rates that are supported by precious metals funds are ill-advised, adding precious metals fund shares to a conventional stocks and bonds portfolio does not appear to benefit most retired investors. The findings do support greater allocations to bonds rather than stocks.
\end{abstract}

Keywords: Precious metals, gold, retirement investing, portfolio survival rates, withdrawal rates

\section{INTRODUCTION}

hen the U. S. stock market began its descent in late 2007, the bull market in gold bullion had already
begun. Average monthly London Fix PM gold prices rose from $\$ 655.49$ in June 2007 to $\$ 945.67$ in
June 2009 (Austin Rare Coins, Inc. 2009). As most other investments crashed in concert, gold was one of the few ports in the economic storm. For retired investors stability of value that supports steady withdrawals through troubled times is an important investment objective that was achieved mainly by bond investments. However, in late 2008 and early 2009 corporate bonds failed to provide the expected diversifying gains investors expect in a bear market for stocks. In fact, except for U. S. Treasury issues, bonds followed stocks in their further decline in late 2008. The rapid gain in gold prices through the period of cascading stock and bond prices suggests that precious metals may be the ultimate diversifying asset in financial panics. The question addressed in this paper is whether investing in precious metals via mutual fund shares provides sufficient return and diversification characteristics to materially increase the probability of portfolio survival through retirement payout periods. In the sections below we discuss various means of investing in precious metals, review relevant literature, describe the data and methodology that we rely on in our analysis, and present our findings.

\section{INVESTING IN PRECIOUS METALS}

There are various mechanisms for investing in precious metals. The most obvious to many is the purchase and possession of bullion. Such holdings are somewhat inconvenient in that they must be stored safely, insured, and assayed with each transaction. The bid-ask spread for small quantities of precious metals may widen so that the realized rate of return upon sale after expenses is may be less than anticipated. Gold and silver coins are another means of investing in precious metals. Like bullion coins must be stored safely, insured, and perhaps examined by experts to avoid counterfeits. They too may have wide bid-ask spreads that significantly reduce realized returns. Coins may also have numismatic value that is separate from the value of the metal, and those interested in coin collecting for investment purposes are well-advised to develop expertise to avoid unfortunate surprises in numismatic values. Bullion and coins have the disadvantage of no income yield unless the investor chooses to sell quantities periodically, which incurs transaction costs. 
Gold and silver futures contracts are traded on commodities exchanges and provide means of speculating on the future values of those commodities. Futures contracts are leverage-inherent securities that require special expertise, diligence, time, and more capital than many retirees may wish to commit to futures trading.

Gold and silver backed exchange traded funds (ETFs) are a recent financial innovation. Data on the prominent gold and silver ETFs, iShares COMEX Gold (IAU, NYSEARCA), SPDR Gold Shares (GLD, NYSEARCA) and the silver-backed ETF is iShares Silver Trust (SLV, NYSEARCA) are published online by Yahoo! (Yahoo! Inc., 2009). Since ETFs are backed by trusts that hold the underlying assets, the precious metals ETFs ideally should provide a means of indirect investing that achieves the return, risk, and diversification of the underlying precious metals. ETFs trade through each business day, may be sold short, and are easily and quickly liquidated. However, the returns to the gold ETFs are not closely correlated to the returns on gold bullion as measured by changes in average London PM Gold Fix prices (Austin Rare Coins, 2009). Also the precious metals ETFs are rather new, the two gold ETFs starting in late 2005 and the silver ETF in 2006. Because of their liquidity on the NYSEARCA and backing by bullion, precious metals ETFs offer very promising means of achieving and maintaining desired portfolio diversification with minimal management expense.

Shares of mutual funds that invest in companies that are engaged in the exploration, mining, processing, and distribution of precious metals and that also invest directly in precious metals have been available to investors since the late 1980's. A prominent example is the Vanguard Precious Metals and Mining mutual fund (VGPMX) that currently has a net asset value of just over $\$ 3.0$ billion. Another is a Fidelity fund, Fidelity Select Gold (FSAGX) with net assets of about $\$ 2.50$ billion, that focuses on investments in shares of gold mining companies, gold bullion, gold coins, and in shares of companies that manufacture gold jewelry and related gold products. Since the shares of gold and silver mining companies and companies that hold precious metals for production purposes gain from increases in the value of the underlying metals, the mutual fund shares are an indirect, low expense, and liquid method of achieving the much of the benefits of investing in the precious metals.

\section{LITERATURE REVIEW}

The use of gold as an investment extends back to ancient times, finding full expression in the legends of King Midas and King Croesus of Lydia. Only recently, however, have researchers begun to investigate the risk/return qualities of gold with modern statistical methods. The first such study is that of Herbst (1983), who found that over the period $(1800$ - 1976) gold significantly underperformed equities as an investment, even when excluding cash dividends from equity returns. However, Herbst also argues that because of its unique statistical properties (i.e., negative covariances with equities), gold might be a reasonable investment for a diversified portfolio.

Barr and Afflect-Graves (1985) find that the vehicle chosen for investment in gold is important. Specifically, they find that an investment in the shares of gold mining companies significantly outperforms the direct investment in gold bullion. A confounding factor, however, is that the only gold mining stocks they consider are South African mining shares during the 1970s.

In a more recent study, Adrangi, Chatrath, and Raffie (2003) find a significant positive relationship between gold returns and expected inflation, even controlling for the effect of inflation on real economic activity. Thus, they argue, gold provides a meaningful hedge against expected inflation. Hiller, Draper, and Faff (2006) find that gold, silver, and platinum all have low correlations with equity index returns, using daily returns over the 1976 - 2004 sample period. They find that precious metals have particularly high hedging capability during periods of abnormal stock market volatility. They conclude that investment portfolios that contain precious metals significantly outperform all equity portfolios over the 1976 - 2004 data period.

Ratner and Klein (2008) investigated the usefulness of gold as a component in an internationally diversified portfolio. They find, for the 1975 - 2005 period, that gold significantly improves the performance of an internationally diversified equity portfolio, relative to an all equity portfolio. They also find, however, that gold significantly underperforms equities as a stand-alone investment. 


\section{DATA AND METHODOLOGY}

In view of the finding in the literature that we reviewed on precious metals, gold in particular, as a portfolio investment, we examined the usefulness of precious metals investment in retirement portfolios, focusing ultimately on the impact of precious metals investments on the sustainability of a range of withdrawal rates. The medium we chose to examine is share in mutual funds that invest in precious metals, as described above. The funds we chose, the Vanguard and the Fidelity funds mentioned above, and USAA Precious Metals and Minerals (USAGX) are comparatively large funds with at least 20 years of historical prices and returns data. The share price and dividend histories of those mutual funds from September 1988 through December 2008 were downloaded in Excel format from Yahoo! Inc., 2009 at http://finance.yahoo.com/. The total monthly returns to shares in the three mutual funds were averaged each month in the sample period to represent an investor's expected periodic return each month from investing indirectly in precious metals. The averaged monthly returns to the precious metals funds were considered in combination with returns to portfolios of common allocations to large company common stocks and high-grade corporate bonds. Large company common stocks were represented in the analysis by returns to the Standard \& Poor's 500 Index (S\&P 500), and corporate bonds were represented by the returns to the Lehman Brothers highgrade bond index (now a Barclay's product). Monthly returns to the S\&P 500 index and high-grade corporate bonds for our sample are published in Morningstar's (2009) SBBI Yearbook. The 244-month average monthly returns, standard deviations of returns, and correlations for the precious metals mutual funds, large company stocks, and corporate bonds are reported in Table 1 below. Average returns and standard deviations of portfolios were converted to annual values for the Monte Carlo simulations.

As may be observed in the summary statistics below, average annual returns to precious metals funds are greater than those to S\&P 500 stocks and high-grade corporate bonds. However the annualized standard deviation of returns to precious metals funds was more than double that of S\&P 500 stocks and almost four times the standard deviation of returns to corporate bonds. The portfolio advantage that precious metals funds have is the negative correlation with stocks and comparatively low correlation with corporate bonds. In order to determine whether precious metals funds would enhance returns relative to risk in a portfolio that includes S\&P 500 stocks and corporate bonds, a portfolio optimization model that maximized portfolio risk premium relative to standard deviation identified the optimal portfolio weight to be 0.0757 or 7.57 percent of the market value of the portfolio with the remaining weight divided between S\&P 500 stocks and corporate bonds with the greatest weight given to bonds (0.6906).

\begin{tabular}{|c|c|c|c|}
\hline \multicolumn{4}{|c|}{ Table 1} \\
\hline \multicolumn{4}{|c|}{$\begin{array}{l}\text { Descriptive Data and Monthly Returns Correlations Among Precious Metals Funds, } \\
\text { S \&P } 500 \text { Stocks, and High-Grade Corporate Bonds: } 1988 \text { - } 2008\end{array}$} \\
\hline & Precious & & \\
\hline & metals & S\&P 500 & Corporate \\
\hline & funds & Stocks & bonds \\
\hline Average annualized returns & 0.1170 & 0.0921 & 0.0876 \\
\hline Annualized standard deviations & 0.3122 & 0.1443 & 0.0843 \\
\hline \multicolumn{4}{|l|}{ Correlations: } \\
\hline Precious metals funds & 1.0000 & & \\
\hline S\&P 500 stocks & -0.0431 & 1.0000 & \\
\hline Corporate bonds & 0.1367 & 0.1840 & 1.0000 \\
\hline \multicolumn{4}{|c|}{$\begin{array}{l}\text { Note: Monthly returns to precious metals funds are averaged monthly returns to three } \\
\text { precious metals funds, VGPMX, FSAGX, and USAGX for September } 1988 \text { to December } \\
2008 \text { as published by Yahoo! Inc. (2009). Returns for those same months to S\&P } 500 \\
\text { stocks and high-grade corporate bonds are published by Morningstar (2009). }\end{array}$} \\
\hline
\end{tabular}


While the optimal allocation is interesting, the important question for a retired investor is whether an asset class supports withdrawals. In order to address that question for shares in precious metals funds, we calculated the portfolio survival rates for payout periods of 15 years, 20 years, 25 years, 30 years, and 35 years via Monte Carlo simulation in two stages. First we calculated portfolio survival rates for conventional stocks/bonds portfolios, and then we recalculated portfolio survival rates for the same conventional stocks/bonds portfolios plus the optimal allocation of the portfolio of precious metals mutual funds. The three conventional stocks/bonds portfolios asset allocations that we examined were 75 percent S\&P 500 stocks and 25 percent corporate bonds (75/25), 50 percent S\&P 500 stocks and 50 percent corporate bonds (50/50), and 25 percent S\&P 500 stocks and 75 percent corporate bonds (25/75). In the next set of simulations each of those allocations was combined with 7.57 percent precious metals funds. That is, 7.57 percent precious metals funds were combined with 92.43 percent allocated to the conventional 75/25, 50/50, and 25/75 stocks/bonds portfolios. We assume annual rebalancing of all portfolio allocations.

Portfolio survival rates were calculated from the simulated end-of-period portfolio values. Those portfolios that completed payout periods with positive values were the survivors. The end-of-period values are calculated in the following equation:

$P_{t}=P_{t-1}\left(1+r_{p t}\right)-W_{t-1}(1+i)$

in which $\mathrm{Pt}$ is the remaining value of the portfolio at the end of time period $t, \mathrm{P}_{\mathrm{t}-1}$ is the value of the portfolio at the beginning of time period $t$, the variable $r_{p t}$ is the total return to the portfolio in time period $t$, and $\mathrm{W}_{t-1}(1+\mathrm{i})$ is the amount of the withdrawal at the end of time period $t$. The variable $i$ adjusts $\mathrm{W}_{\mathrm{t}-1}$ for inflation which is assumed to be a constant 3 percent in this analysis. The withdrawals begin with a designated withdrawal rate of 3 percent and range to 8 percent of the initial portfolio value and then annual amounts of withdrawals are increased by the 3 percent annual compound growth rate. Thus regardless of the assumed initial withdrawal rate, the withdrawal amounts grow 3 percent each year.

The annual calculation of $\mathrm{P}_{\mathrm{t}}$ for an asset allocation and an initial withdrawal rate continued to the completion of payout periods of the 15,20,25,30, and 35 payout periods or until the portfolio is depleted whichever occurred first. The simulation program calculated the survival rate from the results of 1000 iterations for each payout period, portfolio asset allocation, and withdrawal rate. The percentage of simulated portfolio that survived the 1000 iterations is reported as the survival rate for that combination of portfolio asset allocation and initial withdrawal rate. Portfolio survival rates with the optimal precious metals funds allocation through the payout periods then were compared to the portfolio survival rate of the stocks/bonds-only portfolios. Monte Carlo simulation in our analyses assumes long-normal distributions of annual portfolio returns. No adjustment was made for serial correlation or mean reversion.

\section{FINDINGS}

Investing in shares of precious metals mutual funds would be of advantage to retired investors if the portfolio survival rates were materially enhanced by the optimal allocation of those funds in retirement portfolios. In Table 2 we report the portfolio survival rates of the stocks/bonds-only portfolios. In comparison to previous studies, we note the strong showing corporate bonds. Those earlier studies report higher portfolio survival rates with greater allocations of large company stocks. In Table 2 the 25/75 stocks/bonds portfolios provided the highest survival rates among the three asset allocations. The negative returns to stocks in 2008 and poor performance in 2007 no doubt weighed heavily in the effect of stock allocations on portfolio survival rates. Future stock returns may restore the advantage of stocks versus bonds in retirement portfolios.

In Table 3 the simulated portfolios included the optimal 7.57 percent allocation to precious metals mutual funds plus the stocks/bonds allocations in Table 2. A cursory review of Table 3 suggests little meaningful difference in the portfolio survival rates with precious metals funds versus those portfolios in Table 2 that include stock and bonds only. The differences between the portfolio survival rates in Table 3 and those in Table 2 were calculated and reported in Table 4 where the more interesting differences are boxed. The 75/25 stocks/bonds portfolios appear to benefit most from the addition of shares in precious metals funds when the withdrawal rates are greater than $6 \%$ and the payout is among the longer payout periods. One notable improvement occurred when adding the precious 
metals funds to the 50/50 stocks/bonds portfolio. The average portfolio survival rate net of initial withdrawals of 5 percent increased to 85.6 percent for the 35 -year payout period, which is a respectable probability of survival. Still the portfolio survival rates in Table 2 or Table 3 for the higher withdrawal rates and longer payout periods are quite low and thus risky for retired investors. Therefore this research suggests that there is not much portfolio survival advantage to investing in the precious metals funds at the apparent optimal proportion of 7.57 percent of the portfolio.

\section{SUMMARY AND CONCLUSIONS}

Shares in precious metals mutual funds were combined in the optimal proportion of 7.57 percent with portfolios of large company stocks and high-grade corporate bonds to evaluate the effects of indirect precious metals investments on the sustainability of a range of initial withdrawal rates of 3 percent to 8 percent for payout periods of 15 years to 35 years. Portfolio survival rates for withdrawal rates of 6 percent to 8 percent through longer payout periods were increased somewhat by the inclusion of precious metals mutual fund shares in portfolios. Because almost all of the enhanced portfolio survival rates were still quite low for those withdrawal rates and payout periods, the inclusion of the precious metals shares cannot be expected to significantly increase portfolio survival rates for most retired investors. The only relevant combination of withdrawal rate and payout period that benefited materially from the precious metals shares was the 5 percent withdrawal rate for 35 years from the $50 / 50$ stocks/bonds portfolio combined with precious metals shares. Bonds performed much better in this experiment than in earlier studies. The poor performance of stocks in recent years has reduced their favorable effect on portfolio survival rates.

Future research on this topic should focus on precious metals ETF shares as more direct investments in precious metals. ETFs have liquidity through each trading day and can be sold short. When sufficient history has developed on returns to precious metals ETFs, the impact of those investments on portfolio survival rates should be a more interesting study.

\section{AUTHOR INFORMATION}

Carl M. Hubbard is Professor of Business Administration at Trinity University where he teaches financial management and investment analysis. He serves on various university committees and boards of trustees. He has authored and coauthored articles in academic and professional journals including the Journal of Finance, Financial Management, Financial Services Review, Financial Counseling and Planning, the AAII Journal, the Journal of Business \& Economics Research, and the Journal of Financial Planning.

Daniel T. Walz is Professor of Business Administration at Trinity University in San Antonio, Texas. Dan has written widely in the area of personal financial planning with articles appearing in Financial Services Review, the Journal of Financial Planning, Financial Planning and Counseling, and the Journal of the American Association of Individual Investors. Dan recently served as President of the Academy of Financial Services

\section{REFERENCES}

1. Adrangi, B, A Chatrath, and K: Raffiee. "Economic Activity, Inflation, and Hedging: The Case of Gold and Silver Investments." The Journal of Wealth Management, 2003: 60-77.

2. Austin Rare Coins, Inc. 2009. London Gold Bullion Market Historical PM Gold Fix, Monthly Average Gold Prices (1968 - 2009) http://goldprices.com/GoldHistory.htm

3. $\quad$ Barr, G., and J. Affleck-Graves. "Gold Shares of Gold Bullion - Which is the Better Investment." Managerial and Decision Economics, 1985: 241-245.

4. Herbst, A. "Gold versus U.S. Common Stocks: Some Evidence on Inflation Hedge Performance and Cyclical Behavior." Financial Analysts Journal, 1983: 66-74.

5. $\quad$ Hiller, D, P Draper, and R Fall. "Do Precious Metals Shine? An Investment Perspective." Financial Analysts Journal, 2006: 98-106.

6. Morningstar. 2009. Ibbotson 2009 SBBI Classic Yearbook. Chicago, Ill: Morningstar, Inc.

7. Ratner, M. Klein, S. "The Portfolio Implications of Gold Investment." The Journal of Investing, 2008: 7787.

8. Yahoo! Inc. 2009. Yahoo Finance. http://finance.yahoo.com (accessed August 2009) 
Table 2

Monte Carlo Simulations of Survival Rates of Stock and Bond Portfolios Net of Annual Withdrawals That Grow 3\% Annually: 1988 - 2008 Returns Data

\begin{tabular}{|c|c|c|c|c|c|c|c|}
\hline & & \multicolumn{6}{|c|}{ Annual withdrawal rate $+3 \%$ annual COLA } \\
\hline \multicolumn{2}{|c|}{ Portfolios/Payout Periods } & $3 \%$ & $4 \%$ & $5 \%$ & $6 \%$ & $7 \%$ & $\mathbf{8 \%}$ \\
\hline \multicolumn{8}{|c|}{$75 \%$ Stocks $/ 25 \%$ Bonds } \\
\hline 15 & years & $100.0 \%$ & $100.0 \%$ & $100.0 \%$ & $99.5 \%$ & $95.0 \%$ & $78.5 \%$ \\
\hline 20 & years & $100.0 \%$ & $100.0 \%$ & $99.1 \%$ & $92.1 \%$ & $70.0 \%$ & $36.8 \%$ \\
\hline 25 & years & $100.0 \%$ & $99.7 \%$ & $96.6 \%$ & $78.8 \%$ & $42.6 \%$ & $17.5 \%$ \\
\hline 30 & years & $100.0 \%$ & $99.0 \%$ & $88.4 \%$ & $60.2 \%$ & $26.7 \%$ & $9.3 \%$ \\
\hline 35 & years & $100.0 \%$ & $96.8 \%$ & $85.5 \%$ & $49.5 \%$ & $17.9 \%$ & $5.0 \%$ \\
\hline \multicolumn{8}{|c|}{$50 \%$ Stocks $/ 50 \%$ Bonds } \\
\hline 15 & years & $100.0 \%$ & $100.0 \%$ & $99.9 \%$ & $99.2 \%$ & $92.2 \%$ & $74.8 \%$ \\
\hline 20 & years & $100.0 \%$ & $100.0 \%$ & $98.0 \%$ & $87.9 \%$ & $68.2 \%$ & $41.3 \%$ \\
\hline 25 & years & $100.0 \%$ & $99.3 \%$ & $93.2 \%$ & $75.3 \%$ & $42.1 \%$ & $20.4 \%$ \\
\hline 30 & years & $99.9 \%$ & $97.1 \%$ & $86.1 \%$ & $60.8 \%$ & $27.5 \%$ & $9.8 \%$ \\
\hline 35 & years & $99.7 \%$ & $96.4 \%$ & $77.7 \%$ & $48.8 \%$ & $22.5 \%$ & $7.4 \%$ \\
\hline \multicolumn{8}{|c|}{$25 \%$ Stocks $/ 75 \%$ Bonds } \\
\hline 15 & years & $100.0 \%$ & $100.0 \%$ & $99.9 \%$ & $99.8 \%$ & $94.8 \%$ & $79.8 \%$ \\
\hline 20 & years & $100.0 \%$ & $100.0 \%$ & $99.4 \%$ & $91.2 \%$ & $70.4 \%$ & $37.1 \%$ \\
\hline 25 & years & $100.0 \%$ & $99.8 \%$ & $96.9 \%$ & $79.6 \%$ & $43.9 \%$ & $16.5 \%$ \\
\hline 30 & years & $100.0 \%$ & $98.5 \%$ & $90.3 \%$ & $62.4 \%$ & $27.0 \%$ & $7.7 \%$ \\
\hline 35 & years & $100.0 \%$ & $97.9 \%$ & $83.4 \%$ & $47.6 \%$ & $21.0 \%$ & $5.7 \%$ \\
\hline
\end{tabular}

Note: Each survival rate was calculated from 1,000 iterations of Monte Carlo simulation.

Annualized monthly returns of portfolios and annualized standard deviations were the inputs. Returns to the S\&P 500 and high-grade corporate bonds are published in Morningstar (2009) and historical price and dividend data for calculating total returns to the mutual funds are published by Yahoo! Inc. (2009) at http://finance.yahoo.com. 
Table 3

Monte Carlo Simulations of Survival Rates of Stock, Bond, and Precious Metals Fund Shares Portfolios Net of Annual Withdrawals That Grow 3\% Annually: 1988 - 2008 Returns Data

\begin{tabular}{|c|c|c|c|c|c|c|c|}
\hline & & \multicolumn{6}{|c|}{ Annual withdrawal rate $+3 \%$ annual COLA } \\
\hline \multicolumn{2}{|c|}{ Portfolios/Payout Periods } & $3 \%$ & $4 \%$ & $5 \%$ & $6 \%$ & $7 \%$ & $8 \%$ \\
\hline \multicolumn{8}{|c|}{$(75 S / 25 B)+$ Gold funds } \\
\hline 15 & years & $100.0 \%$ & $100.0 \%$ & $100.0 \%$ & $97.6 \%$ & $88.7 \%$ & $75.1 \%$ \\
\hline 20 & years & $100.0 \%$ & $99.8 \%$ & $97.5 \%$ & $88.4 \%$ & $65.8 \%$ & $41.0 \%$ \\
\hline 25 & years & $99.7 \%$ & $98.8 \%$ & $90.0 \%$ & $70.9 \%$ & $47.1 \%$ & $23.4 \%$ \\
\hline 30 & years & $99.4 \%$ & $95.2 \%$ & $84.7 \%$ & $59.1 \%$ & $36.1 \%$ & $18.7 \%$ \\
\hline 35 & years & $99.6 \%$ & $93.9 \%$ & $75.2 \%$ & $53.4 \%$ & $29.7 \%$ & $12.9 \%$ \\
\hline \multicolumn{8}{|c|}{$(50 \mathrm{~S} / 50 \mathrm{~B})+$ Gold funds } \\
\hline 15 & years & $100.0 \%$ & $100.0 \%$ & $99.9 \%$ & $99.7 \%$ & $94.4 \%$ & $78.7 \%$ \\
\hline 20 & years & $100.0 \%$ & $100.0 \%$ & $99.2 \%$ & $91.4 \%$ & $70.7 \%$ & $42.1 \%$ \\
\hline 25 & years & $100.0 \%$ & $99.5 \%$ & $95.0 \%$ & $78.0 \%$ & $47.7 \%$ & $21.2 \%$ \\
\hline 30 & years & $100.0 \%$ & $98.7 \%$ & $88.5 \%$ & $65.0 \%$ & $33.7 \%$ & $11.7 \%$ \\
\hline 35 & years & $99.8 \%$ & $97.3 \%$ & $85.6 \%$ & $53.2 \%$ & $25.7 \%$ & $9.1 \%$ \\
\hline \multicolumn{8}{|c|}{$(25 S / 75 B)+$ Gold funds } \\
\hline 15 & years & $100.0 \%$ & $100.0 \%$ & $100.0 \%$ & $99.7 \%$ & $96.4 \%$ & $80.7 \%$ \\
\hline 20 & years & $100.0 \%$ & $100.0 \%$ & $100.0 \%$ & $94.1 \%$ & $75.2 \%$ & $41.2 \%$ \\
\hline 25 & years & $100.0 \%$ & $99.9 \%$ & $96.3 \%$ & $79.8 \%$ & $47.2 \%$ & $19.8 \%$ \\
\hline 30 & years & $100.0 \%$ & $99.4 \%$ & $93.9 \%$ & $65.1 \%$ & $32.2 \%$ & $9.8 \%$ \\
\hline 35 & years & $100.0 \%$ & $98.2 \%$ & $84.1 \%$ & $52.5 \%$ & $21.9 \%$ & $5.8 \%$ \\
\hline
\end{tabular}

Note: Each survival rate was calculated from 1,000 iterations of Monte Carlo simulation.

Annualized monthly returns of portfolios and annualized standard deviations were the inputs. Returns to the S\&P 500 and high-grade corporate bonds are published in Morningstar (2009) and historical price and dividend data for calculating total returns to the mutual funds are published by Yahoo! Inc. (2009) at http://finance.yahoo.com. 


\section{Table 4}

Portfolio Survival Rate Advantages of Holding Precious Metals Fund Shares in Addition to Portfolios of Common Stocks and Corporate Bonds: 1988 - 2008 Returns Data

\begin{tabular}{|c|c|c|c|c|c|c|c|}
\hline & & \multicolumn{6}{|c|}{ Annual withdrawal rate $+3 \%$ annual COLA } \\
\hline \multicolumn{2}{|c|}{ Portfolios/Payout Periods } & $3 \%$ & $4 \%$ & $5 \%$ & $6 \%$ & $7 \%$ & $8 \%$ \\
\hline \multicolumn{8}{|c|}{$(75 S / 25 B)+$ Gold funds } \\
\hline 15 & years & $0.0 \%$ & $0.0 \%$ & $0.0 \%$ & $-1.9 \%$ & $-6.3 \%$ & $-3.4 \%$ \\
\hline 20 & years & $0.0 \%$ & $-0.2 \%$ & $-1.6 \%$ & $-3.7 \%$ & $-4.2 \%$ & $4.2 \%$ \\
\hline 25 & years & $-0.3 \%$ & $-0.9 \%$ & $-6.6 \%$ & $-7.9 \%$ & $4.5 \%$ & $5.9 \%$ \\
\hline 30 & years & $-0.6 \%$ & $-3.8 \%$ & $-3.7 \%$ & $-1.1 \%$ & $9.4 \%$ & $9.4 \%$ \\
\hline 35 & years & $-0.4 \%$ & $-2.9 \%$ & $-10.3 \%$ & $3.9 \%$ & $11.8 \%$ & $7.9 \%$ \\
\hline \multicolumn{8}{|c|}{$(50 \mathrm{~S} / 50 \mathrm{~B})+$ Gold funds } \\
\hline 15 & years & $0.0 \%$ & $0.0 \%$ & $0.0 \%$ & $0.5 \%$ & $2.2 \%$ & $3.9 \%$ \\
\hline 20 & years & $0.0 \%$ & $0.0 \%$ & $1.2 \%$ & $3.5 \%$ & $2.5 \%$ & $0.8 \%$ \\
\hline 25 & years & $0.0 \%$ & $0.2 \%$ & $1.8 \%$ & $2.7 \%$ & $5.6 \%$ & $0.8 \%$ \\
\hline 30 & years & $0.1 \%$ & $1.6 \%$ & $2.4 \%$ & $4.2 \%$ & $6.2 \%$ & $1.9 \%$ \\
\hline 35 & years & $0.1 \%$ & $0.9 \%$ & $7.9 \%$ & $4.4 \%$ & $3.2 \%$ & $1.7 \%$ \\
\hline \multicolumn{8}{|c|}{$(25 S / 75 B)+$ Gold funds } \\
\hline 15 & years & $0.0 \%$ & $0.0 \%$ & $0.1 \%$ & $-0.1 \%$ & $1.6 \%$ & $0.9 \%$ \\
\hline 20 & years & $0.0 \%$ & $0.0 \%$ & $0.6 \%$ & $2.9 \%$ & $4.8 \%$ & $4.1 \%$ \\
\hline 25 & years & $0.0 \%$ & $0.1 \%$ & $-0.6 \%$ & $0.2 \%$ & $3.3 \%$ & $3.3 \%$ \\
\hline 30 & years & $0.0 \%$ & $0.9 \%$ & $3.6 \%$ & $2.7 \%$ & $5.2 \%$ & $2.1 \%$ \\
\hline 35 & years & $0.0 \%$ & $0.3 \%$ & $0.7 \%$ & $4.9 \%$ & $0.9 \%$ & $0.1 \%$ \\
\hline
\end{tabular}

Note: Differences in Monte Carlo simulations of portfolio survival rates of stock and bond portfolios versus portfolios of stocks, bonds, and gold mutual fund shares. Annualized monthly returns of portfolios and annualized standard deviations were the inputs. Returns to the S\&P 500 and high-grade corporate bonds are published in Morningstar (2009) and historical price and dividend data for calculating total returns to the mutual funds are published by Yahoo! Inc. (2009) at http://finance.yahoo.com. 